\title{
cox6C wt Allele
}

National Cancer Institute

\section{Source}

National Cancer Institute. COX6C wt Allele. NCI Thesaurus. Code C52027.

Human COX6C wild-type allele is located within 8q22-q23 and is approximately $16 \mathrm{~kb}$ in length. This allele, which encodes cytochrome c oxidase polypeptide VIc protein, plays a role in electron transfer in the mitochondrial electron transport chain. 